\title{
An Immodest Proposal: How the Kansas Supreme Court Can Unify the Uniform Trade Secret Act's Preemption of Common Law Claims*
}

\author{
I. INTRODUCTION
}

Imagine that a small business in Wichita, Kansas, that manufactures conveyor pizza ovens finally begins a dramatic expansion in anticipation of signing a contract to supply all of the ovens for Domino's Pizza. About a year earlier, the small business had hired a human resources consultant to help with this expansion. This new employee has been successful in his human resources role, so the business discusses with him the possibility of serving as president of the company. He agrees, and the business has its attorney draft an employment agreement, which the employee signs. The employment contract includes a restrictive covenant that prohibits the employee from revealing the business's trade secrets and other confidential business information.

Unfortunately, the small business's relationship with its new president starts to sour. The president decides to resign after receiving a number of formal reprimands and a two-day, unpaid suspension. He cleans out his desk and file cabinet upon his departure. After separating from the business, the now-former employee decides to start his own company. He calls his uncle who has a Ph.D. in food science and had previously worked in research and development. He also calls the owner of a metal fabrication company. Together, they form a company that manufactures commercial pizza ovens. As their first order of business, they decide to reverse engineer a pizza oven his former employer-the small business-manufactures. The business has no patent protection. Within three months, the new company has successfully assembled its first oven.

After hearing that its former employee had assembled a pizza oven in such a short period of time, the small business begins to suspect that the

* Ashley Dillon. J.D. candidate 2013, University of Kansas School of Law; B.A., B.J. 2010, University of Missouri. I would like to thank my family and friends for their support, the University of Kansas Law Review board and staff for their hard work and dedication, and Professor Suzanne Valdez for her invaluable feedback. 
former employee took trade secrets and other confidential information to aid in replicating the oven. After receiving calls from several vendors indicating that the former employee has ordered from them the same parts that the small business uses in manufacturing its pizza ovens, the small business's suspicions are essentially confirmed. It decides to file suit against the former employee, claiming that he breached his employment contract, misappropriated the business's trade secrets, and breached his fiduciary duty. The business also files suit against the former employee's new company, asserting claims of misappropriation of trade secrets and tortious interference of a contractual relationship. It alleges that the former employee and his company misappropriated eight pieces of information: (1) a vendor list, (2) a customer list, (3) design drawings, (4) the oven's particular handle, (5) the electrical components, (6) the lifting plates, (7) the oven's layout, and (8) a bill of materials.

Several months after the small business files suit against the former employee, the former employee's new company secures a contract with Wings-N-Things. The small business had viewed Wings-N-Things as a potential customer because it had previously purchased one of its ovens through a distributor.

This factual scenario describes the underlying facts in the recently decided Kansas case Wolfe Electric, Inc. v. Duckworth. ${ }^{1}$ Because the design of its pizza oven and other confidential business information were unpatented, Wolfe Electric had to rely on the Kansas Uniform Trade Secrets Act (KUTSA) for protection. ${ }^{2}$ Essentially, a "trade secret" is some piece of information that the owner wants to keep secret by whatever means available so that nonconsensual release of the information occurs only by a tort or a breach of contract. ${ }^{3}$ This unpatented yet confidential information has become an increasingly important business asset. In Kansas, trade secret law has the power to protect certain important business information; recent examples include a formula for coating elbow pipes, ${ }^{4}$ blood management software, ${ }^{5}$ customer lists, ${ }^{6}$ and a recipe for making pizza sausage. ${ }^{7}$

1. 266 P.3d 516, 519-21 (Kan. 2011).

2. Id. at 520, 533 ("[T]ort causes of action cannot include a claim to recover for trade secrets; KUTSA is the exclusive remedy.”).

3. ConFold Pac., Inc. v. Polaris Indus., Inc., 433 F.3d 952, 959 (7th Cir. 2006).

4. See Progressive Prods., Inc. v. Swartz, 258 P.3d 969, 977-78 (Kan. 2011).

5. See Mediware Info. Sys., Inc. v. McKesson Info. Solutions, LLC, No. 06-2391-JWL, 2007 WL 926142, at*1 (D. Kan. Mar. 26, 2007).

6. See Fireworks Spectacular, Inc. v. Premier Pyrotechnics, Inc., 147 F. Supp. 2d 1057, 1066 
It has become increasingly unclear how widely trade secret protection extends and what claims are available to trade secret owners in the unfortunate event of trade secret misappropriation. Often, litigants seeking to protect their trade secrets and recover for misappropriation pursue a scattershot approach to litigation. ${ }^{8}$ Thus, litigants might file a misappropriation of trade secrets claim under their state's version of the Uniform Trade Secrets Act (UTSA) in conjunction with a number of other potential causes of action including breach of fiduciary duty, tortious interference, misappropriation of confidential information not rising to the level of trade secret, conversion, and various other state law claims. ${ }^{9}$ This was the case in Wolfe Electric, where it was unclear to the trial court how to treat these common law causes of action in combination with claims under the KUTSA. ${ }^{10}$ This lack of clarity resulted in an appeal to the Kansas Supreme Court, which reversed and remanded the case to the trial court because of its misinterpretation of the KUTSA. ${ }^{11}$

Whether a court will allow other claims based on the misappropriation of a trade secret depends on whether the state's adopted version of the UTSA preempts those claims. Great uncertainty exists as to whether courts will permit such claims as there are almost as many different interpretations of this preemption provision as there are common law versions of the UTSA. Despite the purported "uniformity" of a uniform law governing trade secret protection, little uniformity exists in practice.

In Kansas in particular, the federal and state district courts have received little guidance from the higher courts. Neither the Tenth Circuit nor the state's appellate courts have issued a decision that directs how to apply the displacement provision in misappropriation cases. ${ }^{12}$ As a result, trial judges have relied on different approaches used in other jurisdictions that are often as unresolved on this issue as Kansas courts. ${ }^{13}$

(D. Kan. 2001).

7. See C\&F Packing Co. v. IBP, Inc., 224 F.3d 1296, 1303 (Fed. Cir. 2000).

8. See Victoria A. Cundiff, Recent Developments in Trade Secret Law, in INTELLECTUAL PROPERTY COURSE HANDBOOK 785, 811 (2010).

9. Id. at 811-12.

10. See Wolfe Elec., Inc. v. Duckworth, 266 P.3d 516, 533 (Kan. 2011) (“[T]ort causes of action cannot include a claim to recover for trade secrets; KUTSA is the exclusive remedy.”).

11. Id.

12. See infra Part III.A.

13. See infra Part III.A. 
Kansas, however, is in a unique position. Because so little case law has developed on the issue, the appellate courts have an opportunity to definitively decide how to apply the KUTSA displacement provision without overruling precedent or grappling with unfavorable legislation on the issue.

This Note will explore the different methods of applying the UTSA and determine the appropriate method for applying the KUTSA. Part II will begin by examining the background of the UTSA. It will outline the shift from common law trade secret protection to a uniform regime under the statute, and it will discuss the mechanics of the UTSA, such as its components and its necessity in conjunction with other intellectual property regimes. Part II will also review the various methods that courts have used for determining whether other common law claims are displaced. Next, Part III will examine how courts have applied the KUTSA. This section will then propose an interpretation that allows for a uniform application in Kansas and that could serve as a model for uniformity if adopted by other jurisdictions.

\section{BACKGROUND}

\section{A. The Shift from the Common Law to a Uniform Law}

Trade secret law is part of the law of unfair competition. ${ }^{14}$ Trade secret law initially developed through state common law and was eventually included by the American Law Institute in the Restatement (First) of Torts. ${ }^{15}$ Judicial decisions drew guidance from the Restatement of Torts, and "each state constructed, on a case-by-case basis, its own body of trade secret law." ${ }^{\prime 6}$ Building case law in this way, however, led to great inconsistencies and uneven development in the treatment of trade secret protection from state to state, ${ }^{17}$ and the need for a uniform act to

14. Sharon K. Sandeen, The Evolution of Trade Secret Law and Why Courts Commit Error When They Do Not Follow the Uniform Trade Secrets Act, 33 HAMLINE L. REV. 493, 495 (2010).

15. See id. at $500-01$.

16. Linda B. Samuels \& Bryan K. Johnson, The Uniform Trade Secrets Act: The States' Response, 24 CREIGHTON L. REV. 49, 49-50 (1990).

17. In the prefatory note to the UTSA, the committee responsible for drafting the Act stated: Notwithstanding the commercial importance of state trade secret law to interstate business, this law has not developed satisfactorily. In the first place, its development is uneven. Although there typically are a substantial number of reported decisions in states that are commercial centers, this is not the case in less populous and more agricultural jurisdictions. Secondly, even in states in which there has been significant litigation, there 
codify the principles of common law trade secret protection became a concern for the National Conference of Commissioners on Uniform State Laws (NCCUSL). ${ }^{18}$ The Patent Section of the American Bar Association also recognized a need for "a uniform state law to protect against the wrongful disclosure or wrongful appropriation of trade secrets, knowhow[,] or other information maintained in confidence by another." 19 Thus, the NCCUSL drafted the UTSA, acknowledging the power of trade secret law in guiding ethical business practices ${ }^{20}$ and the need to consolidate and harmonize the common law principles while filling gaps left by the courts. ${ }^{21}$

The NCCUSL approved and recommended the UTSA for enactment in $1979 .^{22}$ The UTSA was later amended in 1985 to improve its linguistic clarity. ${ }^{23}$ The UTSA's adoption by the NCCUSL, however, was not enough to give it the force of law; the legislature of each state had to enact the UTSA. ${ }^{24}$ As a result, the evolution from the Restatement's view of trade secrets to the UTSA's reinterpretation was a slow process. ${ }^{25}$ On September 2, 1988, Alaska became the twenty-sixth state to adopt the UTSA, which resulted in the UTSA displacing the Restatement as the predominant body of law governing trade secrets. ${ }^{26}$

At present, forty-six states, the District of Columbia, Puerto Rico, and the Virgin Islands have adopted some version of the UTSA. ${ }^{27}$ So far in 2012, Massachusetts has introduced the act. ${ }^{28}$ New York, North Carolina, and Texas have not adopted any version of the UTSA. ${ }^{29}$ Kansas enacted the Kansas Uniform Trade Secrets Act (KUTSA) in

is undue uncertainty concerning the parameters of trade secret protection, and the appropriate remedies for misappropriation of a trade secret.

UNIF. TRADE SECRET ACt Prefatory Note (amended 1985), 14 U.L.A. 531 (2005).

18. See id.

19. Id.

20. See Samuels \& Johnson, supra note 16, at 50.

21. See Why States Should Adopt UTSA, UNIF. LAW COMM’N, http://www.nccusl.org/Narrative. aspx?title=Why\%20States\%20Should\%20Adopt\%20UTSA (last visited Mar. 11, 2012).

22. Samuels \& Johnson, supra note 16 , at 50.

23. See id.

24. See Sandeen, supra note 14, at 538.

25. See id.

26. Id.

27. Legislative Fact Sheet-Trade Secrets Act, UNIFORM LAW COMM’N, http://www.nccusl.org/ LegislativeFactSheet.aspx?title=Trade\%20Secrets\%20Act (last visited Mar. 11, 2012).

28. Id.

29. See Acts: Trade Secrets Act, UnIFORM LAw COMM'N, http://www.nccusl.org/Act.aspx? title=Trade\%20Secrets\%20Act (last visited Mar. 11, 2012). 
$1981{ }^{30}$ and in 1988 , the Kansas Legislature amended it to reflect the UTSA’s 1985 amendments. ${ }^{31}$

\section{B. The Mechanics of the UTSA}

\section{The UTSA Compared to Other Intellectual Property Regimes}

The UTSA works in conjunction with patent and other intellectual property law to protect developers and users of commercially valuable ideas and technology. ${ }^{32}$ Two major differences exist between trade secret law and patent law. First, and perhaps most significantly, trade secret law does not utilize a registration system-like that employed in patent law-where the owner of a trade secret may publicly identify its property rights before a conflict arises. ${ }^{33}$ The result is that patents are open to public inspection while trade secrets must remain protected as secrets to retain their value. ${ }^{34}$ Second, a patent affords its owner a timelimited monopoly over the patented technology, and any use of that technology during that limited time constitutes an infringement. ${ }^{35}$ Trade secret law, on the other hand, only protects an owner against the wrongful acquisition and subsequent improper appropriation of the protected information. ${ }^{36}$ A trade secret loses protection through the owner's voluntary use and disclosure or through a third party's discovery of the secret "through legitimate, good faith means, such as reverse engineering." 37 So, although it is lawful to "steal” a trade secret by discovering it through reverse engineering, a patent is good against the whole world, including those who acquire the information through good faith means. ${ }^{38}$ Thus, an owner's property right in a trade secret is defined

30. See Progressive Prods., Inc. v. Swartz, 258 P.3d 969, 974 (Kan. 2011).

31. See 1988 Kan. Sess. Laws 1333, ch. 221 (codified at Kan. STAT. ANN. §§ 60-3320 to -3333 (2005)); UNIF. TRAdE SECRETS ACt §§ 2(b), 3(a), 7, 11 (amended 1985), 14 U.L.A. 619, 633-34, 651 (2005).

32. Progressive Prods., 258 P.3d at 976.

33. Cundiff, supra note 8 , at 787.

34. Progressive Prods., 258 P.3d at 976.

35. Evans v. Gen. Motors Corp., 976 A.2d 84, 92 (Conn. Super. Ct. 2007).

36. Id.

37. Id.

38. See ConFold Pac., Inc. v. Polaris Indus., Inc., 433 F.3d 952, 959 (7th Cir. 2006) (citing Bonito Boats, Inc. v. Thunder Craft Boats, Inc., 489 U.S. 141, 155-56 (1989); Rockwell Graphic Sys., Inc. v. DEV Indus., Inc., 925 F.2d 174, 179 (7th Cir. 1991); Am. Can Co. v. Mansukhani, 742 F.2d 314, 334 n.24 (7th Cir. 1984)). 
by the extent to which the owner can effectively maintain its secrecy by preventing its disclosure to others. ${ }^{39}$

\section{The UTSA's Components}

The UTSA provides the owner of a trade secret with a civil action for compensatory damages, ${ }^{40}$ punitive damages, ${ }^{41}$ attorney's fees, ${ }^{42}$ and injunctive relief ${ }^{43}$ if the owner of such information can show (1) that the information is a trade secret as defined by the UTSA ${ }^{44}$ and (2) actual or threatened misappropriation of the information. ${ }^{45}$ To prevail on a misappropriation of trade secrets claim in Kansas, the plaintiff must show "that the defendants employed theft or breached a duty to maintain secrecy in order to acquire trade secrets that had an independent

39. Progressive Prods., 258 P.3d at 976.

40. Section 3(a) of the UTSA provides that a plaintiff "is entitled to recover damages for misappropriation." It provides that "[d]amages can include both the actual loss caused by misappropriation and the unjust enrichment caused by misappropriation that is not taken into account in computing actual loss.” UNIF. TRADE SECRETS ACT § 3(a) (amended 1985), 14 U.L.A. 633-34 (2005).

41. UNIF. TRADE SECRETS ACT § 3(b) ("If willful and malicious misappropriation exists, the court may award exemplary damages in an amount not exceeding twice any award made under subsection (a).”).

42. A court may award attorney's fees to the prevailing party in the event that "(i) a claim of misappropriation is made in bad faith, (ii) a motion to terminate an injunction is made or resisted in bad faith, or (iii) willful and malicious misappropriation exists.” UNIF. TRADE SECRETS ACT § 4.

43. See UNIF. TRAdE SECRETS ACT § 2.

44. The UTSA defines a "trade secret" as:

[I]nformation, including a formula, pattern, compilation, program, device, method, technique, or process, that: (i) derives independent economic value, actual or potential, from not being generally known to, and not being readily ascertainable by proper means by, other persons who can obtain economic value from its disclosure or use, and (ii) is the subject of efforts that are reasonable under the circumstances to maintain its secrecy.

UNIF. TRADE SECRETS ACT § 1(4).

45. The UTSA defines “[m]isappropriation” as:

(i) acquisition of a trade secret of another by a person who knows or has reason to know that the trade secret was acquired by improper means; or (ii) disclosure or use of a trade secret of another without express or implied consent by a person who (A) used improper means to acquire knowledge of the trade secret; or (B) at the time of the disclosure or use, knew or had reason to know that his knowledge of the trade secret was (I) derived from or through a person who had utilized improper means to acquire it; (II) acquired under circumstances giving rise to a duty to maintain its secrecy or limit its use; or (III) derived from or through a person who owed a duty to the person seeking relief to maintain its secrecy or limit its use; or (C) before a material change of his [or her] position, knew or had reason to know that it was a trade secret and that knowledge of it had been acquired by accident or mistake.”

UNIF. TRADE SECRETS ACT § 1(2). 
economic value and that these secrets were not readily ascertainable by proper means by the defendants." ${ }^{46}$ The plaintiff must also demonstrate that it made reasonable efforts to maintain the information in secrecy. ${ }^{47}$ The KUTSA, however, does not require the owner to employ a particular means of protecting a secret; it only requires that the owner protect the secret with "efforts that are reasonable under the circumstances to maintain its secrecy."48

\section{Section 7: The "Effect on Other Law" Provision}

Section 7 of the UTSA expressly provides that it displaces conflicting tort, restitutionary, and other state law providing civil remedies for misappropriation of a trade secret. ${ }^{49}$ Section 7 expressly does not displace contract claims, criminal remedies, or claims under federal law. ${ }^{50}$ The Kansas equivalent of section 7 is the "Application of act" provision, which has adopted the exact language of the UTSA. ${ }^{51}$

The NCCUSL's 1985 amendments produced substantial changes to the language of section 7; nevertheless, the content remained substantially similar to the 1979 original. $^{52}$ The concern regarding section 7's original language was that it "did not make it clear that the UTSA would not preclude breach of contract claims and associated contract remedies." ${ }^{\text {53 }}$ Thus, the 1985 amendments clarified that section 7 was not intended to displace contractual liability and contractual remedies for misappropriation. ${ }^{54}$ Of the forty-six states that have adopted the UTSA, three states-Iowa, Nebraska, and New Mexico-

\footnotetext{
46. Progressive Prods., Inc. v. Swartz, 258 P.3d 969, 976 (Kan. 2011).

47. Id.

48. Id. at 978 (quoting KAN. StAT. ANN. § 60-3320(4)(ii) (2005)) (internal quotation marks omitted).

49. UNIF. TRAdE SECRETS ACT § 7.

50. Id. See Cundiff, supra note 8 , at 812.

51. The KUTSA provides that: "this act displaces conflicting tort, restitutionary and other law of this state providing civil remedies for misappropriation of a trade secret.” KAN. STAT. ANN. § 603376(a). Subsection (b) then provides that "this act does not affect: (1) Contractual remedies, whether or not based upon misappropriation of a trade secret; (2) other civil remedies that are not based upon misappropriation of a trade secret; or (3) criminal remedies, whether or not based upon misappropriation of a trade secret.” Id. § 60-3326(b). Compare id. § 60-3376, with UNIF. TRADE SECRETS ACT $§ 7$.

52. Samuels \& Johnson, supra note 16 , at $88-89$.

53. See Sandeen, supra note 14, at 536.

54. Samuels \& Johnson, supra note 16, at 89.
} 
chose not to adopt section $7 .^{55}$ Further, five states-Arkansas, Connecticut, Indiana, Louisiana, and Washington-have not adopted the 1985 amendments. ${ }^{56}$ Several states-including California and Illinoishave modified the language of section $7 .{ }^{57}$ Kansas adopted the section 7 language verbatim. ${ }^{58}$

Section 7 was necessary to achieve the underlying purpose of the act: to create uniformity in the varying causes of action and legal theories of trade secret protection. ${ }^{59}$ The UTSA could not accomplish its uniformity goal, however, unless it first wiped the slate clean by displacing the preceding common law that had accumulated. ${ }^{60}$ Although the UTSA and its displacement provision have been applied widely in the states that have adopted it, there has been a great lack of consistency in its application. Moreover, a lack of consensus exists regarding the proper application and the intended scope of the provision.

\section{Methods for Determining Displacement of State Law}

There are almost as many schools of thought attempting to reconcile the different state and federal courts' interpretations of the UTSA's displacement provision as there are court decisions. ${ }^{61}$ Analysts of these

55. John T. Cross, UTSA Displacement of Other State Law Claims, 33 HAMLINE L. REV. 445, 448 (2010).

56. Id. at 449 .

57. Id. (noting that the Illinois UTSA explicitly includes unfair competition in section 7(a) and that the California UTSA only discusses its effect on other California statutes).

58. Compare Kan. Stat. AnN. §60-3326 (2005), with Unif. Trade Secrets Act § 7 (amended 1985), 14 U.L.A. 651 (2005).

59. See Cross, supra note 55, at 446 ("UTSA $\S 7$ is the linchpin of this harmonization."); see also Burbank Grease Servs., LLC v. Sokolowski, 693 N.W.2d 89, 98 (Wis. Ct. App. 2005), rev'd in part, 717 N.W.2d 781, 788-94 (Wis. 2006) (stating that "the purpose of the preemption provision is to preserve a single tort action under state law for misappropriation of a [statutory] trade secret ... and thus to eliminate other tort causes of action founded on allegations of misappropriation of information” (citing Leucadia, Inc. v. Applied Extrusion Techs., Inc., 755 F. Supp. 635, 637 (D. Del. 1991))).

60. See Sandeen, supra note 14, at 533-34 (“[T]he UTSA would not accomplish its central mission if the (often inexact and incomplete) legal theories and causes of action that preceded it were allowed to co-exist. Thus, what ultimately became $\S 7$ of the UTSA (Effect on Other Law) was proposed.”).

61. Generally speaking, there is a lack of uniformity even in the way legal analysts and judges who have attempted to apply the displacement provision have categorized and applied the various approaches to interpreting the displacement provision. Although the three interpretations enumerated in this section might not be the exclusive means of interpreting the provision, the difficulty in grouping the different schools of analysis into distinct categories further lends support to the proposition that a more uniform approach is necessary. 
trends have attempted to group courts' decisions into different methods of assessing whether the UTSA preempts a particular claim; however, 
there has been little success in attempting to reconcile these different lines of cases. ${ }^{62}$

\section{The Scope of the UTSA}

There is fundamental discord among courts regarding the UTSA's scope. Courts disagree on whether the UTSA should control all confidential information or only information qualifying as a trade secret under the definition provided in the UTSA. ${ }^{63}$ Courts generally follow

62. Professor Cross observes that courts disagree on the UTSA's subject matter and "on whether the UTSA is meant to govern all secrets, or only those secrets that qualify as a UTSA trade secret." Cross, supra note 55, at 451 . He further notes that "even when courts find that the information in question falls within the subject matter of the UTSA, they differ on what test to use to determine whether a state law claim is displaced.” Id.

Cundiff's assessment differs somewhat, noting that "there are at least two distinct trends followed by courts assessing whether particular claims are preempted." Cundiff, supra note 8, at 812. She posits that "[t]he majority view is that whether a claim is pre-empted by the [UTSA] should generally be determined at the pleading stage, or at least early on." Id. If it is apparent at the pleading stage "that a plaintiff has merely restated its trade secrets claims as separate tort claims ...., but the claims in fact all arise out of the same nucleus of common facts as the trade secrets misappropriation claim, then the claims are pre-empted and should be promptly dismissed." Id. Cundiff states that the minority view is that even information not qualifying as a trade secret may still be protected as "confidential information" under common law causes of action. Id.

Courts have offered varying interpretations. One line of cases holds that UTSA preempts only those civil claims based upon trade secrets as defined in the statute, but does not preempt civil claims based on information that fails to meet that statutory definition.” See, e.g., Mediware Info. Sys., Inc. v. McKesson Info. Solutions, LLC, No. 06-2391-JWL, 2007 WL 926142, at * 2 (D. Kan. 2007) (citing Burbank Grease Servs., LLC v. Sokolowski, 717 N.W.2d 781, 793 (Wis. 2006)). The court further explained that "[a]nother line of cases holds that determining whether the allegedly misappropriated information constitutes a trade secret is irrelevant for preemption purposes because the UTSA preempts all claims based upon the unauthorized use of information, even if the information does not meet the statutory definition of a trade secret." Id. (citing Cenveo Corp. v. Slater, No. 06-CV-2632, 2007 WL 527720, at *3 (E.D. Pa. Feb. 12, 2007); Genzyme Corp. v. Bishop, 463 F. Supp.2d 946, 949 (W.D. Wis. 2006)). Another court explained that other UTSA jurisdictions have not been uniform in their interpretation of the displacement provision. Powell Prods., Inc. v. Marks, 948 F. Supp. 1469, 1474 (D. Colo. 1996). As it observed, "[s]everal courts have stated that where a plaintiff alleges in his complaint that information was misappropriated and that such information constituted trade secrets, all claims that are factually related to that misappropriation are preempted.” Id. (citing Hutchinson v. KFC Corp., 809 F. Supp. 68, 71 (D. Nev. 1992)). The court continued by observing that "[o]ther courts reason that a plaintiff should be permitted to proceed upon all causes of action 'to the extent that the causes of action have 'more' to their factual allegations than the mere use or misappropriation of trade secrets." Id. (quoting Micro Display Sys., Inc. v. Axtel, Inc., 699 F. Supp. 202, 204-05 (D. Minn. 1988)). The court concluded by noting that "some courts have held that common law tort claims are preempted only 'to the extent directed at trade secret misappropriation,' implying that certain common law claims do not depend upon the information misused being in the nature of a trade secret." Id. (quoting Web Commc'ns Grp., Inc. v. Gateway 2000, Inc., 889 F. Supp. 316, 321 (N.D. Ill. 1995)).

Professor Cross's analysis is the analytical framework used in this Note.

63. See Cross, supra note 55, at 451. The Burbank Grease Servs., LLC v. Sokolowski cases 
two theories when defining the scope of the UTSA's application. ${ }^{64}$ The analysis under each theory helps courts determine whether the information in question falls within the scope of the UTSA and, thus, whether the court even needs to consider the displacement provision. ${ }^{65}$

The first theory assumes that because the UTSA defines the term "trade secret," section 7 does not apply in cases where the information does not rise to the level of a statutorily defined trade secret. ${ }^{66}$ This is essentially a literal reading of the displacement provision. If the information does not meet the statutory definition of a UTSA trade secret, then the plaintiff is free to sue on any of the other potentially overlapping common law claims. ${ }^{67}$

The other theory regarding the breadth of the UTSA allows courts to analyze UTSA displacement when a party brings a common law claim to protect any kind of secret business information, regardless of whether it rises to the level of a UTSA trade secret. ${ }^{68}$ This approach treats the

demonstrate how even two courts in the same state can make fundamentally different decisions about the scope of the UTSA displacement provision. Compare Burbank Grease, 717 N.W.2d at 785 (determining that the displacement provision of the Wisconsin UTSA only applied if the information in question qualified as a UTSA trade secret, thereby leaving undisturbed other civil remedies based on the misappropriation of confidential information), with Burbank Grease Servs., LLC v. Sokolowski, 693 N.W.2d 89, 101-02 (Wis. Ct. App. 2005), rev'd in part, 717 N.W.2d 781 (Wis. 2006) (holding that the Wisconsin UTSA displaces common law claims based on misappropriation of trade secrets or other confidential information even if that confidential information does not meet the statutory definition of a trade secret).

64. See Cross, supra note 55, at 451-52 (noting that courts disagree on what is the "subject matter" of the UTSA and defining what Professor Cross terms the "Trade Secrets Only" view and the "All Confidential Information" view).

65. E.g., Burbank Grease, 717 N.W.2d at 793-94 (finding that it was unnecessary to apply the displacement provision at all because the information in question did not qualify as a UTSA trade secret and that the plaintiffs were free to bring other tort claims relating to the same confidential information underlying the potential UTSA claim).

66. See, e.g., Cenveo Corp. v. Slater, No. 06-CV-2632, 2007 WL 527720, at *3 (E.D. Pa. Feb. 12, 2007) (holding that the Pennsylvania Trade Secrets Act does not displace common law tort claims prior to a determination that the information that is the subject of the suit is a trade secret); Genzyme Corp. v. Bishop, 463 F. Supp. 2d 946, 949 (W.D. Wis. 2006) (holding that until it is determined whether the allegedly misappropriated information rises to the level of a trade secret, the preemption question cannot be addressed).

67. Cross, supra note 55, at 451-52 (“[B]ecause the information in th[e] case was not a trade secret, the plaintiff was free to sue for breach of loyalty and intentional interference with a business relationship, even though these claims dealt with the same underlying facts as a UTSA claim ...." (citing Burbank Grease, 717 N.W.2d at 793-94)); see, e.g., Nucor Corp. v. Bell, 482 F. Supp. 2d 714, 726-27 (D.S.C. 2007) (finding that if the information at issue does not constitute a statutorily defined trade secret, then it is not protected by the South Carolina UTSA and other common law causes of action are available as remedies to the plaintiff).

68. See Cross, supra note 55, at 452; see, e.g., Mortg. Specialists Inc. v. Davey, 904 A.2d 652, 664 (N.H. 2006) (holding that the New Hampshire UTSA "preempts claims that are based upon unauthorized use of information, regardless of whether that information meets the statutory 
UTSA as the sole noncontract and noncriminal protection for any kind of confidential information. ${ }^{69}$ As a result, if the information does not meet the statutory definition of a trade secret, then it might not receive any protection at all. ${ }^{70}$

\section{2. “Tests” for Displacement}

Just as courts disagree on the scope of application for the UTSA, courts have diverging opinions on what "test" to apply to determine whether the statute displaces a plaintiff's other common law claims. ${ }^{71}$ Broadly speaking, courts' treatment of the "Effect on Other Law" provision fall into three categories: field displacement, comparison of elements, and common nucleus of facts. ${ }^{72}$

Some courts interpret the displacement provision to mean that the UTSA displaces all common law causes of action that fall within the subject matter of the UTSA. ${ }^{73}$ This is arguably the broadest test because these courts view the UTSA as the sole protection available for all information potentially falling within the "field" of the UTSA. ${ }^{74}$ There

definition of a trade secret”).

69. Section 7 of the UTSA specifically provides exceptions to its displacing effect only for contractual remedies and criminal remedies. UNIF. TRADE SECRETS ACT § 7 (amended 1985), 14 U.L.A. 651 (2005); see also BlueEarth Biofuels, LLC v. Hawaiian Elec. Co., 235 P.3d 310, 323 (Haw. 2010) (holding that the Hawaii UTSA "preempts non-contract, civil claims based on the improper acquisition, disclosure[,] or use of confidential and/or commercially valuable information that does not rise to the level of a statutorily defined trade secret").

70. Cross, supra note 55, at 453. This interpretation of the scope of the UTSA assumes that the drafters intended for the UTSA to be the sole protection for any kind of confidential information, and that the UTSA intended to deny such protection to information not rising to the UTSA-defined level of "trade secret." Id.

71. Id. at 451.

72. Id. at 454. In an effort to lend some consistency to the analysis of courts' treatment of the displacement provision, Professor Cross outlined three broad "tests" that courts often apply to determine whether a state law claim is displaced. Id. Professor Cross's formulation is by no means the only way to divide up court decisions applying the preemption provision. See supra notes 6162.

73. See, e.g., Omnitech Int'l, Inc. v. Clorox Co., 11 F.3d 1316, 1330 (5th Cir. 1994) (stating that the UTSA cannot be the basis of a breach of fiduciary duty claim and that a plaintiff's breach of fiduciary duty claim is displaced to the extent it is grounded in those allegations). This excludes the contract and criminal remedies for which the UTSA displacement provision makes an exception. See Unif. TRADE SECRETS Act § 7.

74. Professor Cross refers to this as the "field displacement test" because it "mirrors the "field preemption' approach used in connection with certain federal laws." Cross, supra note 55, at 455. That is to say, "[w]hen a court determines that Congress meant for its legislation to occupy a particular field, all state laws touching on that field are automatically preempted." Id. The field displacement view of the "Effect on Other Law" provision "likewise assumes that the UTSA was 
are, of course, different interpretations of this test depending on how broadly the court reads the UTSA. ${ }^{75}$ On the one hand, some courts interpret the UTSA as applying to all types of confidential business information regardless of whether the information rises to the level of a trade secret. $^{76}$ Some courts, on the other hand, take the narrower approach that the UTSA only applies to information rising to the statutorily defined level of a trade secret. ${ }^{77}$

A second approach compares the elements of the common law claim that the plaintiff would like to bring to protect the confidential information with the elements of a UTSA claim for misappropriation of a trade secret. ${ }^{78}$ When the elements significantly overlap, the UTSA displaces the common law claim. When significant differences exist between the claims, however, the common law claim may stand. ${ }^{79}$ There

meant to occupy the field.” Id. This is a loose analogy in that the original UTSA is not actually seen as displacing state laws; rather, the analogy assumes that all other state laws regarding confidential information must be displaced by the UTSA as adopted by that state.

75. For a discussion of the UTSA's scope, see supra Part II.C.1.

76. See, e.g., Ranger Enters., Inc. v. Leen \& Assocs., Inc., Nos. 97-35077, 97-35078, 1998 WL 668380 , at *1 (9th Cir. Sept. 21, 1998) (holding that because "Oregon law does not distinguish between 'trade secrets' and 'confidential information,"” the Oregon UTSA preempts "misappropriation of confidential information claims just as it preempts claims concerning trade secrets” (citing Kamin v. Kuhnau, 374 P.2d 912, 920 (Or. 1962))); see also Cross, supra note 55, at 455 ("Under the majority All Confidential Information view, a court applying the field displacement test treats the UTSA as the only law that imposes a duty on a defendant not to obtain or use someone else's secret. ... Because the UTSA occupies the field of commercially valuable secrets, other state laws can never be used to protect that information.”); supra Part II.C.1.

77. See, e.g., Hecny Transp., Inc. v. Chu, 430 F.3d 402, 404-05 (7th Cir. 2005) (stating that "[t]he dominant view is that claims are foreclosed only when they rest on the conduct that is said to misappropriate trade secrets," so that asserting that a customer list is a trade secret "does not wipe out claims of theft, fraud, and breach of the duty of loyalty that would be sound even if the customer list were a public record”); Craig Neon, Inc. v. McKenzie, 25 Fed. App’x 750, 752 (10th Cir. 2001) (finding that plaintiff's claim was not preempted because the "plaintiff's fraud-and-deceit claim could stand alone even without proving that the [information was] a trade secret" and the Oklahoma UTSA does not apply to civil remedies not based upon misappropriation of a trade secret); Appalachian Railcar Servs., Inc. v. Boatright Enters., Inc., 602 F. Supp. 2d 829, 852 (W.D. Mich. 2008) (finding that where information qualifies as a trade secret under the Michigan UTSA, the common law claims are preempted); BondPro Corp. v. Siemens Westinghouse Power Corp., 320 F. Supp. 2d 804, 808 (W.D. Wis. 2004) (finding the plaintiff's state law claims were displaced by the Wisconsin UTSA to the extent that they are based upon the defendant's alleged improper use of the plaintiff's trade secrets); Stone Castle Fin., Inc. v. Friedman, Billings, Ramsey \& Co., 191 F. Supp. 2d 652, 659 (E.D. Va. 2002) (holding that "unless it can be clearly discerned that the information in question constitutes a trade secret, the Court cannot dismiss alternative theories of relief as preempted by the [Virginia UTSA]").

78. See, e.g., Nucor Corp. v. Bell, 482 F. Supp. 2d 714, 725 (D. S.C. 2007) (determining that the elements of the cause of action under the South Carolina UTSA should be compared to the elements of the common law claim to determine whether a particular cause of action is displaced).

79. An important consideration for the courts applying this interpretation is what constitutes a 
are two variants of this particular approach. Some courts ask whether the common law claim requires a greater number of meaningful elements than does a UTSA claim. ${ }^{80}$ If the common law claim has the same number or fewer elements than a UTSA claim, then the UTSA claim will displace it. ${ }^{81}$ Conversely, if the state law claim requires an element that is not necessary to bring a UTSA claim, then it will generally survive displacement. $^{82}$ Under the second variant of this test, courts examine the elements of the common law claim to determine whether they differ qualitatively from a UTSA claim. ${ }^{83}$

significant difference in the claims.

80. Cross, supra note 55, at 456; see, e.g., Am. Honda Motor Co. v. Motorcycle Info. Network Inc., 390 F. Supp. 2d 1170, 1181 (M.D. Fla. 2005) (stating that the court would dismiss the common law claims "if they contain no material distinction from the [Florida UTSA] claim" and further noting that "if the allegations of trade secret misappropriation alone comprise the underlying wrong, only the [Florida UTSA] claim will survive the motion to dismiss"); Callaway Golf Co. v. Dunlop Slazenger Grp. Ams., Inc., 318 F. Supp. 2d 216, 220-21 (D. Del. 2004) (reasoning that if plaintiff cannot show that its negligence claim is supported by facts other than those underlying the misappropriation of trade secrets claim, then the negligence claim will be preempted); Powell Prods., Inc. v. Marks, 948 F. Supp. 1469, 1474 (D. Colo. 1996) (stating that a plaintiff can bring common law claims that include additional elements not required by a misappropriation claim under the Colorado UTSA); Micro Display Sys., Inc. v. Axtel, Inc., 699 F. Supp. 202, 205 (D. Minn. 1988) (stating that a plaintiff may maintain separate common law "causes of action to the extent that the causes of action have 'more' to their factual allegations than the mere misuse or misappropriation of trade secrets"); Weins v. Sporleder, 605 N.W.2d 488, 492 (S.D. 2000) (finding that "[u]nder the facts of this case, the tort claims and the trade secret claims are inseparable").

81. See Callaway Golf, 318 F. Supp. 2d at 220-21; Powell Prods., 948 F. Supp. at 1474 (finding that the plaintiff's claims for interference with its business relationships did not depend on the determination that the plaintiff's manufacturing process and machine are protectable as trade secrets and, thus, reasoning that the defendants "could be liable for interference with business relations even if they did not misappropriate any trade secrets from plaintiff”).

82. See Am. Honda Motor Co., 390 F. Supp. 2d at 1181 (finding that "material distinctions between [plaintiff's deceptive and unfair trade practices, fraud, and negligent misrepresentation] claims and the [Florida UTSA] claim” saved them from preemption ); Powell Prods., 948 F. Supp. at 1474 (finding that the plaintiff's conspiracy to misappropriate trade secrets claim was not displaced because a conspiracy requires an agreement, which is not an element of a UTSA misappropriation claim); Coulter Corp. v. Leinert, 869 F. Supp. 732, 735 (E.D. Mo. 1994) (finding that the plaintiff's claim of breach of common law duties of confidentiality and loyalty "include[d] allegations beyond disclosure of trade secrets" and therefore were not barred).

83. Cross, supra note 55, at 457; see, e.g., MicroStrategy, Inc. v. Bus. Objects, S.A., 429 F.3d 1344, 1364 (Fed. Cir. 2005) (preempting plaintiff's conspiracy claim because it was predicated on the misappropriation of trade secrets and was not an "independent and alternative conspiracy theory”); Jano Justice Sys., Inc. v. Burton, No. 08-3029, 2008 WL 5191765, at *2 (C.D. Ill. Dec. 11, 2008) (allowing plaintiff's claim for breach of fiduciary duty to survive preemption because conduct beyond the alleged misappropriation would support the claim); Cardinal Health 414, Inc. v. Adams, 582 F. Supp. 2d 967, 985 (M.D. Tenn. 2008) (finding that the plaintiff's civil conspiracy claim was preempted because the "overarching allegation [was] that the defendants conspired to steal confidential and proprietary information, some or all of which may constitute a trade secret"); Auto Channel, Inc. v. Speedvision Network, LLC, 144 F. Supp. 2d 784, 789 (W.D. Ky. 2001) (determining that the Kentucky UTSA does not necessarily displace a cause of action having to do 
A third approach analyzes the facts underlying the state law claim. If the core of facts giving rise to the state law claim is the same as those necessary to bring a UTSA misappropriation claim, then the USTA displaces the state law claim. ${ }^{84}$ These courts have determined that the USTA displaces civil claims deriving from a claim of misappropriation of a trade secret. ${ }^{85}$ Essentially, the court must "look beyond the label of the claims" to the facts supporting the particular state law claim to determine whether the plaintiff has merely restated its misappropriation of a trade secret claim as separate tort claims. ${ }^{86}$ If the common law claim arises from the same facts as the misappropriation of trade secrets claim, then the common law claim is deemed derivative of the misappropriation

with trade secrets if "the plaintiff [only] demonstrates a further factual basis for fraud or deceit that has as an element the use of trade secrets”); Mortg. Specialists, Inc. v. Davey, 904 A.2d 652, 665 (N.H. 2006) (finding that a claim is not preempted "where the elements of the claim require some allegation or factual showing in addition to that which forms the basis for a claim of misappropriation”).

84. Cross, supra note 55, at 458-59. This is the approach most often applied in cases coming from California courts. See, e.g., Ali v. Fasteners for Retail, Inc., 544 F. Supp. 2d 1064, 1070 (E.D. Cal. 2008) (stating that the provision of the California act displaces common law claims that are based on the "identical nucleus" of facts as a trade secrets claim (quoting Silicon Image, Inc. v. Analogix Semiconductor, Inc., No. C-07-0635 JCS, 2007 WL 1455903 (N.D. Cal. May 16, 2007)) (internal quotation marks omitted)); Digital Envoy, Inc. v. Google, Inc., 370 F. Supp. 2d 1025, 1033 (N.D. Cal. 2005) (finding common law unfair competition and unjust enrichment counts based on the same nucleus of facts as a trade secrets claim are displaced under the California UTSA). It is important to note that the language of the displacement provision of the California UTSA differs from that of the original UTSA. See supra note 57 and accompanying text. This approach has spread to other courts. See Chatterbox, LLC v. Pulsar Ecoproducts, LLC, No. CV 06-512-S-LMB, 2007 WL 1388183, at *4 (D. Idaho May 9, 2007) (finding that the plaintiff's claims for unjust enrichment and unfair competition were "based on the same nucleus of facts as its trade secrets claim and, therefore,” were preempted); BlueEarth Biofuels, LLC v. Hawaiian Elec. Co., 235 P.3d 310, 324 (Haw. 2010) (holding that tort, restitutionary, and other laws of Hawaii are displaced by the Hawaii UTSA if the proof establishing the common law claim would also "simultaneously establish" a misappropriation of trade secrets claim (quoting Hauck Mfg. Co. v. Astec. Indus., Inc., 375 F. Supp. 2d 649, 658 (M.D. Tenn. 2004))).

85. On-Line Tech., Inc. v. Bodenseewerk Perkin-Elmer GMBH, 386 F.3d 1133, 1146 (Fed. Cir. 2004) (finding that fraud and unfair trade practices claims were preempted because the plaintiff's allegations related to the misappropriation of trade secrets and "constituted nothing more than [Connecticut UTSA] violations”); Penalty Kick Mgmt. Ltd. v. Coca Cola Co., 318 F.3d 1284, 129798 (11th Cir. 2003) (stating that because the plaintiff's claims of conversion, breach of confidential relationship and duty of good faith, unjust enrichment, and quantum meruit were based upon trade secret, they were superseded by the Georgia UTSA); Secure Energy, Inc. v. Coal Synthetics, LLC, No. 4:08CV1719 JCH, 2010 WL 1691454, at *3 (E.D. Mo. Apr. 27, 2010) (finding that the Missouri UTSA displaces a plaintiff's common law claims that are "[b]ased upon the same facts" as the plaintiff's UTSA claim).

86. Secure Energy, 2010 WL 1691454, at *1 (citing Weins v. Sporleder, 605 N.W.2d 488, 491 (S.D. 2000)); Weins, 605 N.W.2d at 492 ("A plaintiff "may not rely on acts that constitute trade secret misappropriation to support other causes of action.” (quoting Ed Nowogtoski Ins., Inc. v. Rucker, 944 P.2d 1093, 1097 (Wash. Ct. App. (1997)). 
claim and is thus displaced. ${ }^{87}$

Presently, these approaches to the UTSA displacement of common law claims cannot be squarely reconciled. This leaves those with potentially protectable information unsure of how litigation would proceed.

\section{ANALYSIS}

\section{A. Displacement in Kansas Cases}

The difficulty in determining exactly how and when courts should apply the UTSA is particularly apparent in Kansas, as the Kansas Supreme Court has not yet interpreted the KUTSA displacement provision. Although there has been some trade secret litigation in Kansas, very few of these cases have touched upon the issue of displacement, and there has been almost no discussion of displacement in the state's appellate courts. This absence of dispositive decision-making in the state's upper courts has led to a lack of uniformity among lower courts' decisions. ${ }^{88}$ The lower Kansas courts have had to look to other jurisdictions for guidance, yet the lack of uniformity elsewhere has only fostered further inconsistency in Kansas courts' decisions. In addition, Kansas's federal district courts have made a handful of decisions regarding displacement. These courts have applied variations of the above tests but have offered little explanation as to why the KUTSA has displaced a certain claim.

For the first time, the Kansas Supreme Court discussed with some detail the KUTSA "Application of act" section in Wolfe Electric. ${ }^{89}$

87. Secure Energy, 2010 WL 1691454, at *1 (citing Bancorp Servs., LLC v. Hartford Life Ins. Co., No. 4:00-CV-70CEJ, 2002 WL 32727076, at *4 (E.D. Mo. Feb. 25, 2002)). In Secure Energy, the court deemed the plaintiff's claims of breach of fiduciary duty, fraud, negligent misrepresentation, violation of Missouri Uniform Securities Act, tortious interference with contract, unfair competition, and civil conspiracy were preempted by the Missouri Uniform Trade Secrets Act (MUTSA), because they were all merely restatements of the plaintiff's MUTSA claims. Id. at 2-6. Similarly, courts have found that the Illinois Trade Secrets Act (ITSA) "eliminated common law claims based on conduct which might support an ITSA action" and held that "if the operative facts are arguably cognizable under the ITSA, [then] any common law claim that might have been available on those facts in the past now no longer exists in Illinois.” Learning Curve Toys, L.P. v. Playwood Toys, Inc., No. 94 C 6884, 1999 WL 529572, at *3 (N.D. Ill. July 20, 1999).

88. C\&F Packing Co. v. IPB, Inc., No. 93 C 1601, 1994 WL 30540 (N.D. Ill. Feb. 1, 1994), rev'd by 224 F.3d 1296 (Fed. Cir. 2000) (stating that "Kansas courts do not appear to have addressed this precise issue" of the interpretation of the KUTSA preemption provision).

89. Wolfe Elec., Inc. v. Duckworth, 266 P.3d 516, 531-33 (Kan. 2011). 
Although the court declined to explicitly interpret the displacement provision because neither party raised the issue at the trial level, ${ }^{90}$ the court did provide some guidance for the trial court on remand that could indicate how the Kansas Supreme Court would interpret this provision. The court provided that plaintiff Wolfe Electric's trade secrets claims based upon tort-including breach of fiduciary duty and tortious interference-were preempted by KUTSA based upon the language of section $60-3326 .^{91}$ The court's analysis supports the proposition that a common law claim that is merely duplicative of a misappropriation of trade secret claim is displaced by the statutory enactment. ${ }^{92}$ This is a relatively undisputed proposition, however, because the KUTSA codifies the common law misappropriation of a trade secret claim. ${ }^{93}$

The court, in providing the trial court with guidance on remand, emphasized the distinction between information rising to the statutory definition of a trade secret and information that is merely confidential but not a trade secret. ${ }^{94}$ The court concluded that the trial court was "overly inclusive in its [jury] instructions on the claims for recovery for trade secrets and for mere confidential information." 95 This, combined with the court's assertion that the KUTSA is the "exclusive remedy" for recovery on trade secrets, ${ }^{96}$ may support the interpretation that only information rising to the level of a KUTSA trade secret is protectable. The court, however, did not go so far as to explicitly state this proposition. The court merely emphasized the distinction between trade secrets and confidential information to make it clear to the trial court that

90. Id. at $532-33$.

91. Id.

92. Id. at 533. As the court observed:

[T] ]he drafters [of Section 7 of the Uniform Trade Secrets Act, identical to K.S.A. 60-

3326] explicitly abrogate other civil remedies based on misappropriation of a defined trade secret and, among the courts, there seems to be little dispute that the UTSA did, in fact, intend to abrogate other civil remedies when a claim involves misappropriation of trade secrets.

Id. (alterations in original) (quoting Julie Piper, Comment, I Have a Secret?: Applying the Uniform Trade Secrets Act to Confidential Information That Does Not Rise to the Level of Trade Secret Status, 12 MARQ. INTELL. PROP. L. REV. 359, 367 (2008)) (internal quotation marks omitted).

93. See BlueEarth Biofuels, LLC v. Hawaiian Elec. Co., 235 P.3d 310. 314 (Haw. 2010) ("Courts that have considered the UTSA's preemption provision have 'uniformly interpreted [it] to preempt previously existing misappropriation of trade secret actions, whether statutory or common law.”' (alteration in original) (quoting Hauck Mfg. Co. v. Astec Indus., Inc., 375 F. Supp. 2d 649, 654 (E.D. Tenn. 2004))).

94. Wolfe Elec., 293 Kan. at 533.

95. Id.

96. Id. (citing KAN. STAT. ANN. § 60-3326 (2005)). 
its jury instructions must more clearly distinguish between claims that support recovery under KUTSA and claims that do not. ${ }^{97}$

In concluding its analysis, the court made clear that it limited its analysis only to tort claims solely based upon misappropriation of trade secrets by stating that “[a]s for Wolfe Electric's assertion that KUTSA does not displace other tort causes of action for recovery of damages for nontrade secrets, we do not address it for several reasons." "98 Thus, while the Kansas Supreme Court addressed the displacement problem for the first time in Wolfe Electric and provided some guidance for lower courts, the opinion makes it clear that the court is not willing to address the displacement provision until the issue is directly raised on appeal, after a full discussion in the lower courts. ${ }^{99}$

The Kansas federal district court examined the preemption provision for the first time in 1991 in Herbster v. Global Intermediary, Inc., where the defendant moved to dismiss the plaintiff's claims of fraud and breach of the duties of fair dealing and good faith based on the KUTSA preclusion. ${ }^{100}$ Instead of applying any of the tests commonly used by other courts, ${ }^{101}$ the court merely applied the standard for a motion to dismiss. ${ }^{102}$ The court thus limited its inquiry to whether the defendant could show that the plaintiff could prove no set of facts that would entitle him to recovery. ${ }^{103}$ Although the court quoted section 60-3326, the court did not apply that language when making its determination that the plaintiff could bring his breach of implied duty of good faith and fair dealing and fraud claims. ${ }^{104}$ The court did not expressly state that the claims survived potential KUTSA displacement; instead, the court found that the available facts could support the common law claims. ${ }^{105}$

97. Id. The Kansas Supreme Court also stated that the "KUTSA only prohibits misappropriation of 'trade secrets.' It does not mention 'confidential information.' Accordingly, remedies concerning nontrade secrets, e.g., mere confidential information, cannot be obtained through a KUTSA cause of action.” Id. at 523.

98. Id. at 533.

99. See id. ("[T]he parties should be given the opportunity to fully brief and argue the issue, instead of this court attempting to decide it without the benefit of their briefs and arguments and the trial court's analysis.”).

100. No. 89-2198-V, 1991 WL 205659, at*1 (D. Kan. Sept. 11, 1991).

101. See supra Part II.C.2.

102. The standard applied for the motion to dismiss for failure to state a claim was whether "it appears beyond a doubt that the plaintiff can prove no set of facts in support of the theory of recovery that would entitle him to relief.” Herbster, 1991 WL 205659, at *1.

103. Id.

104. Id.

105. Id. Although it is not exactly clear from the facts of the case, it does not appear that the 
The Kansas courts did not again publish an opinion discussing the displacement provision until May 2001, when the topic arose in both Airport Systems International, Inc. v. Airsys ATM, Inc. ${ }^{106}$ and Fireworks Spectacular, Inc. v. Premier Pyrotechnics, Inc. ${ }^{107}$ The district court did not explicitly address the displacement question in Airport Systems because the defendant failed to argue that the plaintiff's KUTSA claim might have precluded its unfair competition claim. ${ }^{108}$ Instead, the court merely stated that " $[\mathrm{w}]$ hile the KUTSA is possibly relevant to the issue of preemption, ... [m]ere passage of the KUTSA does not show that the legislature intended to displace all common law remedies for misappropriation of trade secrets or other confidential business information."109 This statement, in particular, highlights the lower courts' confusion as to how they should apply the KUTSA displacement provision. First, the KUTSA is not merely "possibly relevant to the issue of preemption" of a common law unfair competition claim-it is directly relevant because the Kansas legislature specifically included a displacement provision in section 60-3326. ${ }^{110}$ Second, the "mere passage of the KUTSA" does in fact demonstrate a legislative intent "to displace all common law remedies for misappropriation of trade secrets" because the plain language of section 60-3326(a) clearly states that "this act displaces conflicting tort, restitutionary[,] and other law of this state providing civil remedies for misappropriation of a trade secret." ${ }^{111}$ If the "mere passage" of the KUTSA does not show a legislative intent to effect the application of the KUTSA's plain language, then there would have been little purpose in passing the legislation in the first place.

In Fireworks Spectacular, after concluding that the plaintiff was entitled to recover for misappropriation of trade secrets under the KUTSA, ${ }^{112}$ the federal district court "determin[ed] that, to the extent [the breach of fiduciary duty] claim is based upon [the defendant's] misappropriation of trade secrets, it is duplicative of Plaintiff's claim

\footnotetext{
plaintiff's fraud claim was at all based upon the misappropriation claim in the first place. The court noted that plaintiff alleged that the defendant committed fraud "in inducing him to move to Kansas and perform work without any intention of actually hiring him for his efforts.” Id. Thus, none of the hallmarks of trade secret misappropriation appear to be present in the fraud claim.

106. 144 F. Supp. 2d 1268 (D. Kan. 2001).

107. 147 F. Supp. 2d 1057 (D. Kan. 2001).

108. 144 F. Supp. $2 d$ at 1271 n.4.

109. Id. at 1271.

110. KAN. STAT. ANN. § 60-3326(a) (2005).

111. Id.

112. 147 F. Supp. 2d at 1067.
} 
brought pursuant" to the KUTSA. ${ }^{113}$ Thus, the court found that the KUTSA only partially displaced the plaintiff's claim.

Similarly, in Guang Dong Light Headgear Factory Co. v. ACI International, Inc., the district court considered the defendant's claim of breach of fiduciary duty against a third-party defendant. ${ }^{114}$ The defendant claimed that the third-party defendant had breached its fiduciary duty by accumulating trade secrets for later improper use. ${ }^{115}$ The court determined that because "the KUTSA 'displaces conflicting tort, restitutionary[,] and other law of this state providing civil remedies for misappropriation of a trade secret",116 and "[b]ecause this theory of recovery for breach of fiduciary duty is duplicative of [defendant's] claim brought under the KUTSA, it is displaced by the KUTSA."117 Therefore, the court determined it would not consider the breach of fiduciary duty claim in addition to a misappropriation of trade secrets claim. ${ }^{118}$

In both Fireworks Spectacular and Guang Dong, the court declined to articulate a clear rule or test and instead merely deemed the breach of fiduciary duty claims to be "duplicative" of the misappropriation of trade secrets claims. ${ }^{119}$ As a result, no clear rule emerges from either of these cases as to when a particular common law claim — such as breach of fiduciary duty - is displaced by the KUTSA. Moreover, there is some reason to believe that these district court decisions might conflict with the KUTSA. The comments to the UTSA expressly note that "[t]he Act does not apply to a duty imposed by law that is not dependent upon the

113. Id. at 1068. The plaintiffs argued that the defendant breached his fiduciary duty by "engaging in unfair competition, disclosing and using trade secrets and proprietary information of [the plaintiff] for his own personal benefit and gain.” Id.

114. No. 03-4165-JAR, 2008 WL 53665, at*18 (D. Kan. Jan. 2, 2008).

115. Id.

116. Id. (quoting KAN. STAT. ANN. § 60-3326(a) (2005)).

117. Id.

118. Id.

119. See id. (devoting only one paragraph to the issue of KUTSA displacement and concluding without elaboration that "[b]ecause this theory of recovery for breach of fiduciary duty is duplicative of [the party's] claim brought under KUTSA, it is displaced by the KUTSA"); Fireworks Spectacular, Inc. v. Premier Pyrotechnics, Inc., 147 F. Supp. 2d 1057, 1068 (D. Kan. 2001) (determining that the breach of fiduciary duty claim was displaced by the KUTSA to the extent it was based on the plaintiff's misappropriation of trade secrets claim brought pursuant to the KUTSA). Like in Guang Dong, the court gave the displacement issue only fleeting treatment in a single paragraph and failed to elaborate upon its decision to displace a breach of fiduciary duty claim. Id. In making its decision about the displacement provision's application, the federal district court in Guang Dong relied solely upon the Fireworks Spectacular decision and the language of section 60-3326. See Guang Dong, 2008 WL 53665, at *18. 
existence of competitively significant secret information, like an agent's duty of loyalty to his or her principal."120

The district court explicitly declined to make a determination of how Kansas should apply section 60-3326 in Mediware Information Systems, Inc. v. McKesson Information Solutions, LLC. ${ }^{121}$ The court addressed the split in courts' applications of the different lines of cases and determined that there was no need to "predict which view Kansas would adopt, however, because it [found that] the tortious interference claims alleged by [the plaintiff] in this case [were] not 'based upon misappropriation of a trade secret' and thus [were] not preempted by [section] 60-3326."122 In its determination that the tortious interference claims were not preempted, the court applied what was essentially a combination of two of the above-described tests-the comparison of elements test and the common nucleus of facts test. ${ }^{123}$ The court looked at the facts of each claim along with essential elements of each claim and determined that there were "facts in support of these tortious interference claims [that] would entitle [the plaintiff] to relief, regardless of the success of its misappropriation claim." 124

Taken together, these Kansas cases show an erratic application of section $60-3326 .{ }^{125}$ There has been little uniformity in the manner of the KUTSA's application and in which claims are generally displaced. So far, there has not been a uniform means of applying the KUTSA displacement provision, and Kansas courts have found little help from courts in other jurisdictions given the variety of interpretations available from which to choose.

\footnotetext{
120. UNIF. TRADE SECRETS ACT § 7, cmt. (amended 1985), 14 U.L.A. 651 (2005).

121. No. 06-2391-JWL, 2007 WL 926142, at *2 (D. Kan. Mar. 26, 2007).

122. Id. at *2-3.

123. See supra Part II.C.2.

124. Mediaware, 2007 WL 926142 , at *3.

125. Section 60-3326 has been interpreted in a few instances in other states' courts. For example, the District Court for the Western District of Virginia applied the KUTSA preemption provision to the plaintiff's unjust enrichment claim on a motion to dismiss. Beacon Wireless Solutions Inc. v. Garmin Int'l, Inc., No. 5:11-cv-00025, 2011 WL 4737404, at*13 (W.D. Va. 2011). The court found that the claim was not displaced because "the unjust enrichment claim encompasses more conduct than the mere use and disclosure of confidential information.” Id. The Federal Circuit also briefly interpreted the KUTSA in C\&F Packing Co. v. IBP, Inc., 224 F.3d 1296, 1307 (Fed. Cir. 2000). The court affirmed the district court's finding that the KUTSA displaced the plaintiff's fraud claim because it was "indistinguishable from" the trade secret misappropriation claim. Id. The Federal Circuit did not so much interpret the KUTSA as note that it found no error in the lower court's decision. Id.
} 


\section{B. A Proposed Solution}

Kansas has a unique opportunity to set a precedent as to how states that have adopted the UTSA should apply the displacement provision. Because Kansas courts have developed so little case law on the topic of KUTSA displacement of common law claims and because the case law that has developed is so disjointed, there seems to be no better time than the present to wipe the slate clean and develop a uniform standard. A Kansas Supreme Court decision interpreting this provision would not face any conflicting precedent or poor legislative decisions. Thus, the court has the opportunity to be the first and final arbiter of the legislative intent as expressed in the statute.

A solution to the ambiguity present in the interpretation of section 60-3326, and necessarily section 7 of the UTSA, must consider both the scope of the KUTSA and the appropriate test for determining those claims that it displaces. In order to best fulfill the objectives of the UTSA, Kansas and other UTSA jurisdictions should interpret the UTSA as applying to all claims where a party invokes a common law claim to protect any confidential business information, regardless of whether that information rises to the level of a UTSA trade secret. In order to be effective and to fulfill the UTSA's purpose, this interpretation must be adopted by all UTSA jurisdictions and uniformly applied.

Uniformity seems to have been the underlying goal of the drafters in their attempt to eliminate the various interpretations and applications of trade secret common law through the creation of the UTSA, and Kansas clearly desired a similar result in enacting a uniform law governing trade secrets. The Kansas legislature specifically adopted this goal in section 60-3327's “Uniformity of act” provision, which provides that "[t]his act shall be applied and construed to effectuate its general purpose to make uniform the law with respect to the subject of this act among states enacting it." 126 This section, which mirrors section 8 of the UTSA, makes it clear that the underlying goal of the uniform act is to promote uniformity among all the jurisdictions adopting the act. The Kansas Supreme Court further emphasized this point, stating that the KUTSA "tells us that it seeks uniformity with other jurisdictions that have adopted the [UTSA]."

126. KAN. STAT. ANN. § 60-3327 (2005).

127. Progressive Prods., Inc. v. Swartz, 258 P.3d 969, 976 (Kan. 2011). 
Aside from making the goal of uniformity clear, however, this section provides little guidance to the courts about how they should actually apply the KUTSA. Because the displacement provision is part of a broader statute, a court cannot read it in isolation. Interpretation of this provision requires a court to look to other provisions of the KUTSA for guidance. ${ }^{128}$ Moreover, in addition to simply satisfying the goals of both the KUTSA and the UTSA, a need for interstate uniformity exists because business transactions often cross state borders.

Despite the clear legislative mandate, Kansas courts have paid little attention to the KUTSA's uniformity goal. Some district courts have looked to other jurisdictions to compare different methods of applying the displacement provision, but weighing different jurisdictional doctrines has led to a different doctrinal outcome each time. ${ }^{129}$ Kansas courts must interpret the KUTSA as applying to all claims where a party invokes common law to protect any confidential business information, regardless of whether that information rises to the level of a KUTSA trade secret. ${ }^{130}$ If courts permit common law claims for the unauthorized use of confidential information that does not meet the statutory definition of a trade secret, then they would undermine the uniformity underlying the KUTSA and the UTSA. As the UTSA was originally written, the displacement provision stated that the UTSA would be "the exclusive state tort remedy for trade secret misappropriation." ${ }^{31}$ While questions arose in the drafting as to the exact language of section 7, "there was no dispute about the desirability of such a section."132 Moreover, "[p]ermitting litigants in UTSA states to assert common[]law claims for the misappropriation or misuse of confidential data would reduce the UTSA to just another basis for recovery and leave prior law effectively

128. See Moser v. State Dept. of Revenue, 213 P.3d 1061, 1064 (Kan. 2009) (“Courts should not focus on an isolated part of a legislative act but are required, if possible, to consider and construe together all parts of the act in pari materia.” (citing McIntosh v. Sedgwick Cnty., 147 P.3d 869, 875 (Kan. 2001))).

129. See supra Part III.A.

130. This is the interpretation advocated by Justice Bradley in her dissenting opinion in Burbank Grease Services, LLC v. Sokolowski. 717 N.W.2d 781, 799-803 (Wis. 2006) (Bradley, J., dissenting). The majority held that the Wisconsin UTSA should not apply to misappropriation of confidential information falling outside the statutory definition of a trade secret. Id. at 798 (majority opinion). The majority reasoned that the statute left available all other civil actions that did not depend on information meeting the statutory definition of trade secret. Id.

131. Sandeen, supra note 14, at 534 (quoting Unif. Trade Secrets Protection Act § 6 (First Tentative Draft 1977)).

132. Id. 
untouched.”133 Any other interpretation of KUTSA's preemption penumbra would fail to uphold the goal of promoting uniformity in trade secret protection. Thus, courts should broadly interpret the KUTSA as displacing common law claims that are based solely on allegations of unauthorized use of confidential business information regardless of whether that information meets the statutory definition of a trade secret. Such an interpretation would further the KUTSA and UTSA uniformity goal.

In Learning Curve Toys, L.P. v. Playwood Toys, Inc., ${ }^{134}$ a case from the Northern District of Illinois, the district court emphasized a similar line of reasoning. The court noted that the Illinois version of the UTSA intended to "codify all the various common law remedies for theft of ideas" "135 and that "plaintiffs who believe their ideas were pilfered may resort only to the" Illinois version of the UTSA. ${ }^{136}$ In its analysis, the court considered whether the plaintiff could maintain idea misappropriation and unjust enrichment claims, and it determined that Illinois had "abolished common law theories of misuse of such [secret] information.... Unless defendants misappropriate[d] a statutory trade secret, they [did] no legal wrong." 137 Interestingly, a similar approach has been recognized before in the Kansas case of BioCore, Inc. $v$. Khosrowshahi. ${ }^{138}$ The court observed that Kansas courts do not distinguish between trade secrets and confidential information, stating that "[e]ven if confidential information can be something less than a trade secret, it must at least be a trade secret to give its owner a property right in it.” 139 Although the court might have overstated the past application of such a standard in Kansas, this standard should prevail when courts apply the KUTSA and other UTSA variants.

Moreover, courts should not distinguish between KUTSA-defined trade secrets as actionable under KUTSA and all other confidential information as actionable under Kansas common law. Instead, courts should look at information as actionable or non-actionable-that is, only

\footnotetext{
133. Robert Unikel, Bridging the "Trade Secret" Gap: Protecting "Confidential Information" Not Rising to the Level of Trade Secrets, 29 LOY. U. CHI. L.J. 841, 888 (1998).

134. No. 94 C 6884, 1999 WL 529572 (N.D. Ill. July 20, 1999).

135. Id. (citing Pepsico, Inc. v. Redmond, 54 F.3d 1262, 1269 (7th Cir. 1995)).

136. Id. (citing Powell Prods., Inc. v. Marks, 948 F.Supp. 1469, 1474 (D. Colo. 1996)).

137. Id. (first alteration in original) (quoting Composite Marine Propellers, Inc. v. Van Der Woude, 962 F.2d 1263, 1265 (7th Cir. 1992)).

138. 96 F. Supp. 2d 1221 (D. Kan. 2000), rev'd on other grounds, 80 Fed. App’x 619 (10th Cir. 2003).

139. Id. at 1238 (citing Puritan-Bennett Corp. v. Richter, 679 P.2d 206, 211 (Kan. 1984)).
} 
information protected by the KUTSA would be actionable. ${ }^{140}$ Thus, information should be divided into actionable trade secrets and unprotected information. ${ }^{141}$ The KUTSA would thus eliminate the artificial distinction between information that is a trade secret and other confidential information; instead, all secret information with economic value would fall within the definition of a trade secret. ${ }^{142}$ Such a distinction would emphasize that only information rising to the level of a trade secret receives protection. Common law claims concerning confidential business information that is not a trade secret under KUTSA would no longer be available because all claims stemming from the same acts as the alleged misappropriation are intended to be displaced. ${ }^{143}$ Moreover, such an interpretation places a higher value on the KUTSA's statutory definition of trade secret in section 60-3320.

This interpretation of the KUTSA accords with the commentary provided by the Uniform Law Commissioners on the adoption of the UTSA. ${ }^{144}$ The commentary articulates that a state's dependence on common law remedies for the resolution of disputes involving the misappropriation of trade secrets "creates great uncertainty for industry, particularly for companies that conduct business in more than one state." ${ }^{\prime 45}$ The Commission further underscored the desirability of uniformity, stating that "[e]very state will benefit from the simplicity of

140. See Mortg. Specialists, Inc. v. Davey, 904 A.2d 652, 664 (N.H. 2006) (stating that the New Hampshire UTSA provides that "information is classified only as either a protected 'trade secret' or unprotected 'general... knowledge.'” (quoting Unikel, supra note 133, at 867-68) (internal quotation marks omitted)); accord Allied Erecting \& Dismantling Co. v. Genesis Equip. \& Mfg., Inc., 649 F. Supp. 2d 702, 722 (N.D. Ohio 2009) (“[A]llowing otherwise displaced tort claims to proceed on the basis that the information may not rise to the level of a trade secret would defeat the purpose of the UTSA." (alteration in original) (quoting Bliss Clearing Niagara, Inc. v. Midwest Brake Bond Co., 270 F. Supp. 2d 943, 948-49 (W.D. Mich. 2003))); Silvaco Data Sys. v. Intel Corp., 109 Cal. Rptr. 3d 27, 54 n.22 (Cal. Ct. App. 2010) (Information that does not fit [the definition of trade secret], and is not otherwise made property by some provision of positive law, belongs to no one, and cannot be converted or stolen.”).

141. Edmund W. Kitch, The Expansion of Trade Secrecy Protection and the Mobility of Management Employees: A New Problem for the Law, 47 S.C. L. REV. 659, 662 (1996).

142. Id.

143. In Learning Curve Toys, L.P. v. Playwood Toys, Inc., the court held that a claim may be displaced even if the information at issue does not constitute a trade secret. No. 94 C 6884, 1999 WL 529572, at *3 (N.D. Ill. July 20, 1999); see also Ethypharm S.A. Fr. v. Bentley Pharm., Inc., 388 F. Supp. 2d 426, 433 (D. Del. 2005) ("Because all claims stemming from the same acts as the alleged misappropriation are intended to be displaced, a claim can be displaced even if the information at issue is not a trade secret.”).

144. See Why States Should Adopt UTSA, supra note 21 (underscoring the importance of uniformity and simplicity as policy goals underlying the creation of the UTSA).

145. Id. 
the Uniform Trade Secrets Act" because "[u]nder the common law, some fundamental concepts are disturbingly unclear." "146 Moreover, in its advocacy for the adoption of UTSA, the Commission specifically stressed that UTSA provides uniformity. It stated that "[v]ariations in state law have created confusion about which law should be applied, [which has] encourage[d] litigants to 'forum shop,"” and that "[a]doption of the UTSA by all states would eliminate these problems."147 Forum shopping is problematic because it can lead to problems with unequal protection. Litigants cannot be assured that two courts in Kansas will treat the same trade secret and common law claims similarly because there is so little guidance. ${ }^{148}$ A lack of instruction as to how to apply the statute has fostered arbitrary decision-making. If Kansas truly has adopted the KUTSA for the purpose promulgated by the Commissionthat is to say, if it wants uniformity in the treatment of trade secrets-it must employ a uniform application of the displacement provision to other state law claims. ${ }^{149}$

Comparison of this particular application of the UTSA to a similar provision of the Uniform Deceptive Trade Practices Act (UDTPA) sheds light on an appropriate interpretation of the displacement provision. Section 2(c) of the UDTPA states that it "does not affect unfair trade practices otherwise actionable at common law or under other statutes of this state." 150 The drafters of the UTSA were presumably aware of the displacement language used in the UDTPA ${ }^{151}$ and could have drafted the UTSA "Effect on Other Law" provision similarly to allow further development of common law theories of liability for confidential information not rising to trade secret status. The drafters, instead, used language showing a clear intent to inhibit any further growth of state law theories for the protection of confidential information. ${ }^{152}$

\footnotetext{
146. Id.

147. Id.

148. For a discussion of how the preemption provision has been applied inconsistently by Kansas courts, see supra Part III.A.

149. Cf. Pepsico, Inc. v. Redmond, 54 F.3d 1262, 1269 (7th Cir. 1995) (stating that the purpose of the Illinois UTSA was to codify all the various common law remedies for theft of ideas); Composite Marine Propellers, Inc. v. Van Der Woude, 962 F.2d 1263, 1265 (7th Cir. 1992) (citations omitted) (stating that the Illinois UTSA "abolished all common law theories of misuse of such [confidential] information" and "unless defendants misappropriate[] a (statutory) trade secret, they $\mathrm{d}[\mathrm{o}]$ no legal wrong").

150. Unif. Deceptive Trade Practices Act § 2(c) (repealed 2000), 7A U.L.A. 139 (2005).

151. The NCCUSL adopted the UDTPA in 1966, which predates its creation of the UTSA. Id.

152. Sandeen, supra note 14 , at 534-35.
} 
Similarly, this proposed interpretation of the KUTSA parallels, in some ways, the application of federal patent preemption analysis. ${ }^{153}$ Federal patent protection broadly preempts other federal and state laws because allowing other law to protect patents would undermine "the public policy goals manifested in the patent system taken as a whole.”154 The UTSA similarly has a broad policy goal in favor of uniformity in the protection of confidential business information. ${ }^{155}$ While a comparison to the preemptive effects of federal patent law is in no way dispositive of questions related to the application of the KUTSA and the UTSA-as patent preemption is a matter of federal law preempting state law-some of the underlying principles of federal patent law may instruct the UTSA displacement analysis. In this regard, it might be helpful to think about UTSA displacement in a manner similar to federal preemption. For example, "[w]hen [a] federal statute completely pre-empts the state-law cause of action, a claim [that] comes within the scope of that cause of action, even if pleaded in terms of state law, is in reality based on federal law." ${ }^{156}$ The analog for the KUTSA would be that when a plaintiff pleads common law causes of action pertaining to the misappropriation of trade secrets, the court should read the claims as arising from the KUTSA and analyze them based on KUTSA's requirements.

One should note, however, that this proposed interpretation does somewhat conflict with the comment to section 7 of the UTSA. The comment states:

This Act does not deal with criminal remedies for trade secret misappropriation and is not a comprehensive statement of civil remedies. It applies to a duty to protect competitively significant secret information that is imposed by law. It does not apply to a duty voluntarily assumed through an express or implied-in-fact contract. The enforceability of covenants not to disclose trade secrets and covenants not to compete that are intended to protect trade secrets, for example, is governed by other law. The Act also does not apply to a duty imposed by law that is not dependent upon the existence of

153. See Cross, supra note 55 , at $473-74$.

154. Id. at 473. Professor Cross does concede, however, that although such an interpretation of the UTSA would be in line with federal patent protection, trade secret protection and patent protection are in themselves very different concepts under the law. Id. at 474.

155. See Kan. Stat. ANN. §60-3327 (2005) ("This act shall be applied and construed to effectuate its general purpose to make uniform the law with respect to the subject of this act among states enacting it.”).

156. Beneficial Nat’l Bank v. Anderson, 539 U.S. 1, 8 (2003). 
competitively significant secret information, like an agent's duty of loyalty to his or her principal. ${ }^{157}$

The difficulty with the proposed interpretation, in particular, is that it conflicts with the UTSA comment's proposition that the UTSA "is not a comprehensive statement of civil remedies." 158 The comment seems to prefer an element-by-element analysis for claims. ${ }^{159}$ Such an application of the preemption provision, however, would necessitate a case-by-case analysis of a litigant's claims, which would undermine the Act's uniformity goal. Nevertheless, the application encouraged by the comment might not be the most beneficial for Kansas and other states adopting a version of the UTSA because it belies the purpose of the UTSA to create a uniform act with a uniform application.

Interjurisdictional uniformity would have the positive effect of supplying highly persuasive precedent for Kansas and other states that do not produce large amounts of case law. If all UTSA jurisdictions uniformly applied the preemption provision of the UTSA, then Kansas attorneys, litigants, and judges could rely on the decisions of other jurisdictions for highly persuasive precedent applying to factually similar scenarios.

An approach to the displacement provision that ensures uniformity between jurisdictions applying the UTSA would help business owners with protectable information plan accordingly to ensure that their information will ultimately receive protection. A more uniform approach would also benefit those who transact business in multiple jurisdictions,

157. UNIF. TRAdE SECRETS ACt $\S 7$ cmt (amended 1985), 14 U.L.A. 651 (2005).

158. Id. This portion of the comment, however, could also be referring to the fact that contract claims are specifically saved from displacement in section 7. See id. § 7 .

159. Cross, supra note 55, at 477. Professor Cross suggests that the UTSA displacement provision intended for a court's analysis to "hone in on one particular element of the state law; namely, the nature of the defendant's duty. If the duty exists regardless of whether the information is secret, the Comment indicates the state law is not displaced, even if the information in question is a trade secret.” Id. (citing UnIf. TRAdE SECRETS ACT $\S 7 \mathrm{cmt}$.). Professor Cross further explains that the comment makes clear the difference between section 7(a) and section 7(b)(2), which at first glance seem to say almost the same thing. Id. at 477-78. Section 7(a) speaks to "state laws that 'provide civil remedies' for misappropriation of a trade secret," while section 7(b)(2) pertains to state laws “'based on' misappropriation of a trade secret.” Id. at 477 (quoting UNIF. TRADE SECRETS ACт § 7(a), (b)(2)). He explains that the comment is meant to illuminate the difference that "a state law that is not 'based on' misappropriation of a trade secret is not displaced by the UTSA" whereas "[section] 7(b)(2) makes it clear that displacement applies only when confidentiality is a defining element of the state law claim. If the state law duty remains available even if the information is not secret, the cause of action is not 'based upon' misappropriation of a trade secret, and is not displaced.” Id. at 477-78. 
as less confusion would attend the application of different states' adoptions of the UTSA. One commentator has noted that, although seemingly counterintuitive, applying the displacement provision to "abrogate all other tort remedies for the misuse of confidential information deemed not to be a trade secret does effectuate the best interests of departing employees."160 If the UTSA does not displace all other state law actions for misappropriation of confidential business information not rising to the level of trade secret status, then "employers are able to hold former employees liable for using information not deemed to be a trade secret under a variety of legal theories.”161 Although a narrow interpretation of the displacement provision that allows employers to hold former employees liable for using information not qualifying as a trade secret might sound appealing to employers, such a tactic would allow employers to use the common law to create an implied non-compete contract with departing employees. ${ }^{162}$ Allowing a variety of claims leaves departing employees unsure of what types of claims they might face and, thus, inhibits employee mobility. ${ }^{163}$ Moreover, because such an interpretation could limit the damages an employer could receive, "employers might be more likely to implement employee confidentiality agreements to avoid litigation."164 This, in turn, would encourage better contracting between employers and employees. Increased clarity in what kind of information can be protected under which claims will give business owners the best tools for protecting their trade secrets.

Moreover, such a uniform approach would help attorneys advise clients with greater certainty if they know exactly what type of information the UTSA will protect and which claims will make it past the pleading stage. Otherwise, trade secret litigants might bring as many claims as possible because they are unsure which will survive that jurisdiction's particular test for displacement. ${ }^{165}$ This proposed

160. Piper, supra note 92, at 382.

161. Id.

162. Id. (citing Tait Graves, Nonpublic Information and California Tort Law: A Proposal for Harmonizing California's Employee Mobility and Intellectual Property Regimes Under the Uniform Trade Secrets Act, 2006 UCLA J.L. \& TECH. 1, \10).

163. See Graves, supra note 162, at $\mid 2$ (warning that if employers can sue over information that is not secret or that does not meet the statutory requirements of being a trade secret, then the result is that employee mobility is inhibited).

164. Piper, supra note 92, at 382.

165. Cundiff, supra note 8, at 814 . 
interpretation would thus decrease confusion at the pleading stage. ${ }^{166}$ If a court allows a plaintiff to proceed with common law claims until it has determined whether the information supporting the claims rises to the level of a trade secret, then it draws out litigation and creates another opportunity for the court to undermine the UTSA's uniformity goals. ${ }^{167}$ Conversely, under this proposed approach, it would not matter if a plaintiff's common law claims were based upon trade secrets or merely confidential information because only trade secret information would be protectable. Because common law causes of action protecting against the misappropriation of confidential business information that is not a KUTSA trade secret would no longer be available to plaintiffs, this proposed interpretation would facilitate judges' ruling on motions regarding plaintiffs' causes of action at the early stages of litigation. ${ }^{168}$

Although this proposed interpretation of section 60-3326 might appear harsh, it would not leave unprotected all confidential business information that does not meet the statutory definition of trade secrets. Litigants could still take advantage of the contracts exceptions provided by section 60-3326 regardless of whether the information meets the statutory definition of a trade secret, and this interpretation would encourage thoughtful contracting between parties privy to confidential

166. See Michael A. Jacobs, Michael I. Katz \& Jana G. Gold, Uniform Trade Secrets Act Preemption: An Obscure Doctrine Finally Gets its Day in Court, 12 CYBERSPACE LAW. 15 (2007). As one set of commenters explained:

Under the weak preemption view, courts should not rule on motions to dismiss or for summary adjudication based on preemption, other than to dismiss a common law claim for misappropriation of trade secrets. Under the strong preemption view, defendants can take steps early in the litigation to narrow the scope of the pleadings. By motion or demurrer, a defendant can seek dismissal of statutory and tort-based theories of recovery for theft of confidential information.

Id.

167. See Allied Erecting \& Dismantling Co. v. Genesis Equip. \& Mfg., Inc., 649 F. Supp. 2d 702, 721-22 (N.D. Ohio 2009) (stating "[w]hile some courts have indeed allowed plaintiffs to proceed with common[]law claims until it can be determined whether the information at issue constitutes a trade secret, other courts—representing the majority view—have rejected this approach, and gathering cases").

168. See, e.g., id. at 722 ("Thus, the Court joins the majority view in finding that displacement of common[]law claims may precede the Court's determination of whether the information at issue constitutes a trade secret. To find otherwise would contravene the general purpose of Ohio's UTSA: uniformity.”); see also Graves, supra note 162, at \$3. Graves warns that issues of UTSA preemption are often briefed early on in a case "on crowded motion calendars [and] present[] only surface citations to courts [that] have little time to study these complex issues." Id. Graves asserts that "[a]s a result, the published rulings indicate that courts and attorneys are missing key arguments and considerations, even when they reach the right conclusions.” Id. The adoption of uniform preemption principles could be the cure to attorneys and judges alike having to sift through myriad cases reaching different conclusions. 
business information. This interpretation would also make it incumbent upon the owner of a trade secret to take reasonable measures to protect that information from disclosure to the public. The careful company will take steps to prevent its trade secrets from being disclosed in the first place and, should those secrets be exposed to the public, take precautions to ensure that it protects the information. Employers have a number of tools at their disposal to protect such information. An employer could require employees to sign nondisclosure agreements and conduct exit interviews to impress upon the employees their obligation to prevent information disclosure or theft. Through the use of company policies, employee handbooks, or additional training,

"an employer can make it clear that an employee is only authorized to access [certain information] and is only allowed to copy and transmit the employer's electronic data to further the business interests of the employer and not to promote or further the business interests of the employee or some third party."169

As a further measure, employers can effectively deter information theft by conducting exit interviews and reminding employees of their obligation not to disclose the employer's secrets. ${ }^{170}$ This can be especially effective when "coupled with giving the departing employee a copy of his or her nondisclosure agreement and asking the employee to certify in writing that the employee has returned all” copies of company data. ${ }^{171}$

A trade secret gains its value and protection because the public does not know the information. Thus, the owner must necessarily take measures to protect such information. By implication, only that information requiring such a high level of secrecy deserves protection under the UTSA. By employing good business practices, however, the holder of confidential information can afford it the same level of protection as the information qualifying as a trade secret. Thus, it is clear that a broader interpretation of KUTSA preemption will not leave owners of confidential business information without recourse. This interpretation, instead, will encourage thoughtful and proactive business planning to prevent the disclosure and misappropriation of that

169. John Vering \& Jeffrey L. Schultz, Employees' Misappropriation of Electronic Data: Federal and Kansas Computer Tampering Acts, J. KAN. B. Ass'N. May 2011, at 16, 24-25.

170. Id. at 25 .

171. Id. 
information in the first place.

\section{CONCLUSION}

Absent a strongly uniform interpretation of the UTSA preemption provision, litigants are at the mercy of the whims of the courts. Nearly every case in Kansas regarding the UTSA displacement provision has resulted in a different interpretation, which gives litigants very little direction as to how to prepare for litigation and offer businesses little insight as to how to best protect their information. A uniform interpretation of the displacement provision would remedy the current patchwork of decisions interpreting the displacement of state law claims. To accomplish the goals of the UTSA, courts must interpret the displacement provision in a way that encourages uniformity across the UTSA jurisdictions. Unless the UTSA is seen as the sole means of protecting economically valuable business information, it cannot be uniformly applied. This Note proposes a solution that will achieve the goal of uniformity if adopted widely in Kansas and other UTSA jurisdictions. 